\title{
LIBERALISM IN HISTORICAL PERSPECTIVE
}

\author{
BY PETER N. STEARNS \\ Dr. Stearns is Heinz Professor of History at Carnegie-Mellon University
}

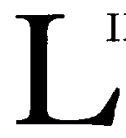

BERALISM was born essentially in the nineteenth century; it is still alive and kicking. In one sense this statement offers no surprise; in the United States particularly, we know that all sorts of people calling themselves liberals abound. In Europe liberalism, by that name, is more limited. British history offers the classic example of the displacement of the Liberal by the Labour party after World War I. Liberals have had only nuisance value since then, as party members. The Italian liberal party, though vital to fragile government coalitions, has been minimal since World War II. Liberal parties in Germany knew their high point in the I870's, and then declined in the face of socialism; since the Second World War the party most clearly claiming the mantle of liberalism runs a distant third.

Yet the theme of this essay is not a requiem. We do need to define what liberalism used to be, but is equally possible, and more important, to say what it has become.

And for this, two preliminaries. First, liberals can be found hiding under many bushes. One must distinguish between liberal parties, formally labeled, and liberals. Again, this is obvious in the United States where liberals exist in both major parties, coexisting uneasily in each with non-liberals. The situation in Europe in only superficially better delineated. The rise of Christian Democratic parties after the War showed a resurgence of liberalism, though not all Christian Democrats are liberals. Socialist parties in western Europe are largely liberal now, despite the apparent paradox involved; important elements have been the main safeguards of liberalism, in countries like Germany, since the turn of the century.

Yet statements of this sort hinge on the second preliminary: what the essence of liberalism is. It is, first of all, a belief in individual self-improvement, even if this improvement necessitates changes in the state and even state assistance. It rests on the notion that individuals can become better, morally, intellectually, as well as materially. Thus, it believes in progress. Not all change has to be 
seen as good, but change is expected and desirable overall. Not only individuals but social organisms can do better than they have before. Liberals believe in science as a matter of progress; they tend to the secular. Most basically, liberals believe in the mind. They welcome intellectual diversity. They are tolerant. But they see the mind as the wellspring of progress. Here is the key identification of the liberal, amid a welter of party labels: the liberal will oppose significant limitations on freedom of press, speech, assembly, religion. And more positively, the liberal will fight for steady improvements in the level of education. Finally, the liberal believes in the ultimate, though not necessarily preexisting, fellowship of human beings. People have as their due an equal opportunity to the goods of life, and again not just material goods. They may make unequal use of them, but they should have the chance or be so formed as to be able to earn the chance. Early liberals, the precise historian must point out, were rarely democrats; they did not believe that the masses had a current potential for effective civic action. Some, including such eminent spokesmen as John Stuart Mill, stressed the inferiority of non-Western peoples. And one could add to the list. But the point is the liberals believed, and believe, that these situations are temporary, reversible, indeed that they should be reversed. People are people, and in fact liberals found it impossible very long to resist extension of suffrage to all men and, relatively soon, to women as well. They found it impossible to defend control of one people by another. Here again, the belief in constructive change is manifest.

All of this leaves the liberal open to accusations of being weakkneed - why should we care about the Bushmen or the liberation of women, when temporarily at least such concern disrupts our lives. It also, from the nineteenth century to the present, has created awkward dilemmas, in that liberals, seeking improvement, might be moved to favor compulsion over groups they regarded as inferior. Not out of spite, for J. S. Mill [in his book On Liberty] children were automatically inferior. They had to be monitored, for they had not attained reason and therefore were not human beings in the liberal sense. But we now realize that the education of children is automatically weighted toward some value system (which children may vigorously reject but cannot ignore). It preaches national loyalty or belief in Christianity or belief in the theory of evolution, all sorts of controversial things. It is impossible to avoid bias in educa- 
tion, so the liberal plea for educating the child was inherently slanted, usually toward an at least vague belief in the progress of science and often against an unduly rigorous religion. Mill also noted African tribes as not yet open to the level of human rationality which his liberalism required. Liberals were long troubled by the issue of imperialism, and I would suggest they still are. If we see people being treated bestially (Bangladesh, the ill-fated revolt of the Ibos in Nigeria) how can we help but howl? The liberal officially opposes imperialism but in practice may support it or other intervention in order to bring the native peoples up to the level where they can be "liberally" treated. The United States remains in this bind, quite apart from the classics of power politics; we don't know when to butt in and when to stay out. Liberals have not done terribly well with children, they have not done justice to women, they have failed miserably with most non-Western peoples-but they have done better than anyone else.

Despite inherent inconsistencies, the notion of reasonably firm liberal principles remains valid: individual rationality, individual and social improvement, ultimate if not immediate equality. This is why liberals, even when not democratic or anti-feminist or anti-nonWestern (to use a ridiculous phrase) rarely can hold out too long against claims to improvement, if not equality, by oppressed groups; and indeed they have often pioneered in more equal legislation, even extended voting rights, before the groups involved had said much one way or the other. It may be to the fault or the credit of liberalism, but many groups have been liberated at least a bit before they asked to be.

Having said this, we must now briefly enter a factual jungle. The initial points must already have occurred: party liberals, as opposed to liberals, often behave illiberally, even given due allowance for human frailty and inconsistency; and we have not included a definite economic position as part of liberalism.

Occasions when apparent liberals become illiberal are numerous. The Revolution of 1830 in France was in appearance a classic liberal rising (though characteristically property owners, the most articulate liberals, stayed out of the street fighting, leaving this to workers). The revolution was reasonably bloodless; liberals tend not to like blood and generally make bad revolutionaries, not only because they fear for property (by no means are all liberals property owners or vice versa) but because they prefer change through evolutionary 
education. After all, if men are rational they should be able to effect calm solutions to the problems of society. But the issues of this particular revolution were classically liberal: the rights of parliament vis-à-vis the executive had been curtailed and freedom of press, teaching, religious toleration all seemed threatened. Yet within six years the new regime cast liberalism aside, making parliament a virtual rubber stamp for the actions of the executive and restricting personal rights by such measures as that forbidding, without official permission, assembly of more than six people. The majority of German Liberals (defined in terms of party membership) at least partially renounced liberalism by the late 1870 's, supporting punitive measures against socialists which radically restricted freedom of press and assembly, two of our key tests of being liberal. In other words, so-called liberal regimes (the post-I 830 July Monarchy in France) and Liberal Parties can lose the essential spirit of liberalism.

As to the second point, liberalism has been hopelessly confused with a precise system of economics, laissez-faire economics to be precise. There was indeed a liberal economic theory, dating from the late eighteenth century, which held that the state should perform minimal functions leaving the clash of individual self-interests to produce the greatest social good. Given history's evolution, this system would, in the twentieth century world, particularly the Anglo-American world, be regarded as conservative. But so-called liberal economics was never integral to the basic liberal current which began at the same time. Few liberal economists cared much about the other aspects of liberalism. Few liberal theorists-again one can use Mill, who became a so-called socialist, as an exampleput maximum private economic initiative high on their list. Why, then, the confusion? Apart from a passion for precise labeling, by which historians and others like to earn their bread: I. a confusion of written theory with actual practice; 2. a confusion of English with more widespread liberalism; 3 . a confusion of liberalism with the middle class, and some confusion about what the middle class was anyway, even in England.

I. Few political advocates of liberalism wanted the state to bow out of the economic arena. American liberals wanted state aid for development of the West, protection of new industry and the like (some non-liberals did too, admittedly; the point is that precise economic stance simply does not define liberalism even in its early heyday). On the European continent one could find a few theorists, 
particularly in France, advocating strict laissez-faire-and it is not ill-placed to note that the illiberal July Monarchy has been noted for liberalism primarily because of its reluctance in economic intervention. But characteristic European liberalism always regarded the state as a potential friend, if oriented toward promotion of material advance, including industrial progress; improved education; and even, though there was a bit of scuffling about this, new kinds of protection of helpless individuals such as children in the early factories. To be sure, liberals wanted and still want a certain kind of state to accomplish this limited economic/social intervention: notably they wanted some representative body and related separation of power to control otherwise untrammeled executive authority. But with rare exceptions they saw nothing wrong with state promotion of railroads, of at least minimal restrictions on child labor abuse, of education (and by the late nineteenth century, compulsory education), and a host of other new activities.

2. England did indeed briefly have a distinctive governmental evolution that can be confused with liberalism. Britain and Norway were the only countries where government functions, as measured by per capita expenditures, declined in the presumed heyday of classical liberalism, up to I850. But England (I regret I cannot comment on Norway, save to note that its pattern must be termed idiosyncratic) had a peculiar industrial advantage. And even with this, it tried illiberally until the I 840's to restrict export of technological knowledge and technicians themselves; it had restrictive tariffs, though by this point, industry well established in part because of eighteenth century protectionism, mainly for agriculture. If it did not build state railroads, it allowed use of the state right of eminent domain for private companies. But grant some special, brief Britannic flair. The United States did not build railroads through the state, to its current regret, but allotted huge amounts of public land to private entrepreneurs; France had a compromise public-private system; Germany and Belgium leaned more toward the state initiative. But the main point is that genuine liberals could support all of these alternatives. To use England as a classic, if evanescent, case of laissez-faire is inaccurate, but even were it true it would simply not be typical. One could be a liberal and advocate protective tariffs, state systems of education, all sorts of new state functions. What liberals definitely did share was a desire to get the state out of old-fashioned economic functions, notably prohibitions 
on technological innovation (e.g. support of guild restrictions) and on the freedom of movement of labor. On the whole, liberals still share this orientation.

3. If one defines the middle class as the middle group of property owners, we must be clear that in the presumed heyday of liberalism most middle-class people were not liberal. Of course this varies with country. But most middle-level property owners looked backward, to older social values. They might briefly think that liberalism would help them move back, but they were quickly disillusioned, as in Germany in $\mathbf{I} 848$, and, possibly, in the United States today. In other words they might think that the government was going astray and that advocacy of restricted state powers would restore traditional community authority, morality, and so on. But they were wrong. Liberalism was progressive, is progressive-though one can freely grant, as a liberal, that it is permissible, if erroneous, to find progress wrong. Middle-class people tended to head liberal movements, as they tended to head most modern political movements, but this does not mean the class should be identified with liberalism. Liberalism could survive even when huge elements of the middle class turned against it, in defense of older values or simply of property. Relatedly, liberalism could draw, sometimes under different labels from those of formal Liberal parties, support from other social groups. Liberalism was and is too vibrant a force to be put under an economically-determinist rubric.

As suggested before, there were many signs that orthodox liberalism had shot its bolt by the later nineteenth century. The German $\mathrm{Na}$ tional Liberal Party was in disarray, having basically sacrificed many liberal principles to the enthusiasm for national unity and power. British Liberals, having achieved modern parliamentary structure, a rudimentary education system, full religious toleration, seemed to lack issues, until after 1900 they turned to limited social insurance measures; and even then they were soon outstripped by more vigorous advocates of the same procedures. But this latter suggests the main point. If we grant that classical liberalism, that of the early nineteenth century, cannot be defined primarily in terms of economics; or by what happened in England; or by any precise formula for state activity - then we can at least entertain the notion that a true liberal spirit survived, perhaps even remained to sparkle, as the western world entered the twentieth century.

One evidence is negative. Political strands that might demonstrate 
strength had to define their issues in terms of what liberals advocated from I 848 to the present; even opposition conservatives found the nature of debate shaped by liberals. At an extreme, movements that dominate our historical consciousness during the period between the World Wars were above all anti-liberal. Of course they shouted against communism, big business and the like, but they were really shouting against liberalism. They wanted women in the home, dressed, in Nazi Germany, in dirndls if possible, bearing children like rabbits. They wanted artistic uniformity. They wanted a non-intellectual, regimented school curriculum. Obviously they won great support, though in a period of unusual stress and never, under anything like free elections, a majority. But if liberalism had died, were they not protesting too much? They had to fight it, and though through efficient police measures they could survive until defeated in war, they did not ultimately triumph.

Liberalism was in fact surviving, in the Western world, in various guises in the twentieth century. Socialism was one. By strict historical canons one should stress the conflict between the two isms. But in fact conflict has proved minimal. Socialists in the Western world (despite American blindness to their flexibility) are tolerant of other political movements, support civil rights-indeed, as in France, they have often been crucial to the preservation or restoration of liberal systems from the Dreyfus affair to the present. Of course they advocate increased state economic intervention, but within bounds, and insofar as in the Western countries these bounds have not been notably overstepped, we have tried to show that this is not out of keeping with the real liberal tradition. With the substantial weeding out of the backward-looking segments of the middle class, support for basic liberal policies has increased. Never, to use one example, has education been so widespread or, in the Western countries, freedom of curriculum and teaching method so extensive. Liberals can, do and should fuss about remaining restrictions, but the point is they are able to work for a classic goal and have progressed toward it. There is much still to fight for, but it's fun to fight; there are many gains to protect as well.

With liberalism properly understood, and with the horror of the period I 9 1 8-1945 put in context (a rather brief period, in historical perspective) we can see liberalism, however, labeled, as the most persuasive of the modern political isms. It cannot be interpreted too rigidly. It has evolved, notably in economic and welfare politics, 
though these are now under renewed scrutiny precisely because of the vitality of the basic liberal premises. It has won at least partial allegiance from a variety of social groups, not only the middle class. It is a spirit, the modern spirit, and very difficult to live with. It involves choice, and tolerance of diversity which come hard to most of us. But it values basic human dignity, and this is at once its essence and its essential value. 